49 | 2018

Human-environment relationships in Siberia and Northeast China. Knowledge, rituals, mobility and politics among the Tungus peoples, followed by Varia

\title{
Visiting Memorial Tree. Micro-geopolitics of an Evenki place composed and performed
}

Visite d'un arbre commémoratif. Micro-géopolitique d'un lieu évenk construit et mis en scène

\section{Gail Fondahl}

\section{OpenEdition}

\section{Journals}

Electronic version

URL: https://journals.openedition.org/emscat/3337

DOI: 10.4000/emscat.3337

ISSN: 2101-0013

Publisher

Centre d'Etudes Mongoles \& Sibériennes / École Pratique des Hautes Études

\section{Electronic reference}

Gail Fondahl, "Visiting Memorial Tree. Micro-geopolitics of an Evenki place composed and performed", Études mongoles et sibériennes, centrasiatiques et tibétaines [Online], 49 | 2018, Online since 20

December 2018, connection on 13 July 2021. URL: http://journals.openedition.org/emscat/3337 ; DOI: https://doi.org/10.4000/emscat.3337

This text was automatically generated on 13 July 2021.

(c) Tous droits réservés 


\section{Visiting Memorial Tree. Micro- geopolitics of an Evenki place composed and performed}

Visite d'un arbre commémoratif. Micro-géopolitique d'un lieu évenk construit et mis en scène

\section{Gail Fondahl}

\section{EDITOR'S NOTE}

Map of the repartition of the Evenki in Russia and China

click here

Positions of the case studies in the present volume

click here

A heartfelt thanks to Anna Sirina for inviting me to take part in the 2005 fieldwork, and for totally enjoyable collaborations; and to Viktor Ganiugin, Denis Shangin, Veronika Simonova, and the many residents of Holodnaia who assisted with information and greeted me with generous hospitality, in 1992, 1994 and 2005. I also thank the many scholars who provided feedback to various presentations of earlier iterations of this paper. I dedicate the essay to the memory of Arkadii Petrovich Lekarev and his energetic if taciturn pedagogy of Trail and Tree. The standard disclaimers apply.

\section{Introduction}

In this paper I consider a walk taken several years ago with colleague Anna Sirina, during the course of fieldwork just north of Lake Baikal, to visit the "Memorial Tree" (Ru. derevo pamiati). Memorial Tree (Fig. 1) commemorates a local reindeer herder who lost his life in World War II. One reaches this Tree (or, rather, dead snag) by hiking the 
“Ecological Trail" (Ru. èkologicheskaia tropa), a path leading from the village of Holodnaia near the north end of Lake Baikal into the taiga, and eventually to the Tree and beyond. Holodnaia is considered an "Evenki" village, the Evenki being one of the indigenous peoples of the Russian Federation". As a geographer interested in indigenous rights to land, I am intrigued by the way indigenous peoples are re-making and performing places ${ }^{2}$, how they are working landscapes actively both to encourage a sense of territorial belonging among their youth and to communicate their assertions of territorial rights to outsiders. The Tree and Trail exemplify such place-(re-)making and territorial assertions; while the guided hike I consider a choreographed performance of these claims.

Figure 1. Memorial Tree

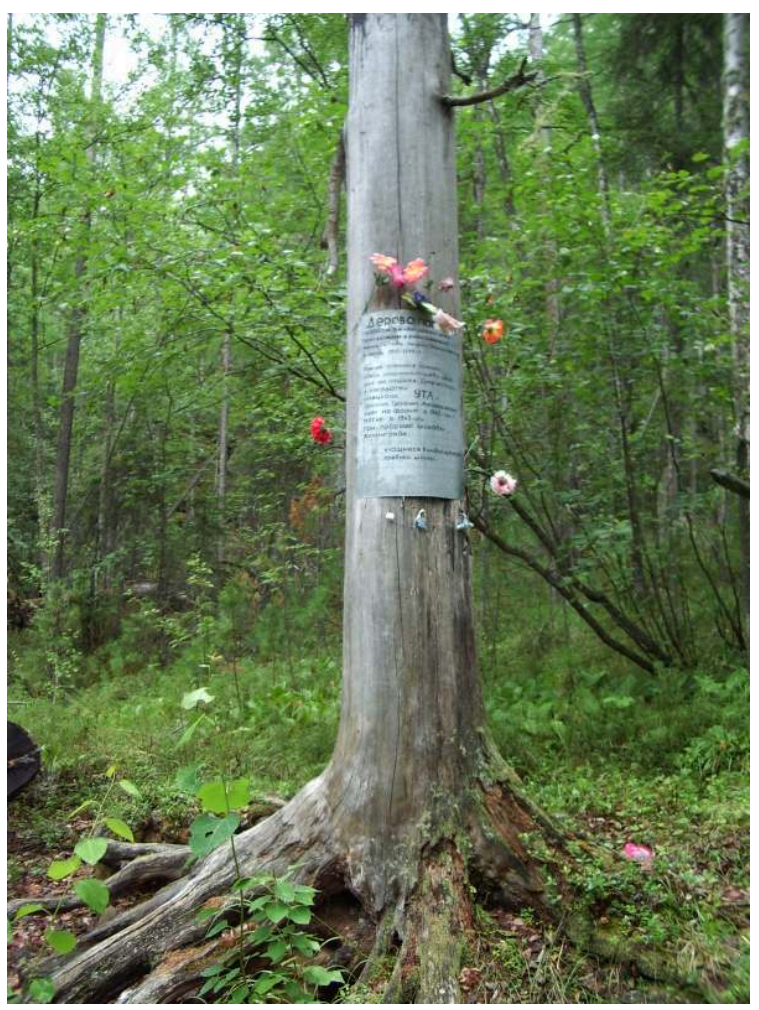

(C) G. Fondahl, August 2005

2 To my delight, during the rather protracted evolution of this paper, I met another researcher, Veronika Simonova, who had walked the same Trail to the same Tree, and was writing about Tree and Trail. Her recently published work (Simonova 2013) discusses this Tree and Trail in terms of the articulation of local memorial practices with official commemorative customs. While I agree with her analysis, mine differs somewhat. This in itself derives from the distinct moments of our walks, the different purposes of our visits, our different identities, and what I imagine to the different agendas of our hosts, given these other differences.

3 I start by describing the immediate geopolitical context of Holodnaia in 2005: the village was faced with the possibility of an oil pipeline being constructed close by. I briefly describe traditional land tenure among the Evenki of this region, then summarize changing land use over the course of the $20^{\text {th }}$ century, including previous encroachments on Evenki territory. A note on the post-Soviet legal reforms that 
address indigenous rights to traditional territory is then provided. With this background established, I introduce the founding of the Trail and Tree as recent constituents of local place-making. Two scales of place-making are identified, each informed by a distinct geopolitical agenda of territorial assertions. I then describe the walk - as a performance staged for several purposes: instructing about the Trail and Tree in a particularly Evenki manner; asserting Evenki and more specifically Kindigir territoriality; and communicating to outsiders the indigenous revival activities in which local Evenki are engaging.

\section{Place-threats}

In the early 2000s, oil pipeline company Transneft planned to build an oil pipeline from central (and yet to be developed) Siberian oilfields to the Pacific Ocean. Several routes for the so-called "Eastern Siberian-Pacific Ocean Pipeline" were considered, and initial reconnaissance pursued. An early preferred routing ran just north of Lake Baikal and within its watershed - in one variant some $80 \mathrm{~km}$ north of the Lake, in another much closer. Significant concern erupted regarding the risk of pipeline fractures and subsequent ecological disaster for Lake Baikal, especially given that the area is one of high seismic activity. At the same time, some found attractive the potential opportunities for jobs related to the pipeline construction, given the difficult economic situation (Fondahl \& Sirina 2006a, pp. 5, 11, Sirina \& Fondahl 2006, p. 253). Anna Sirina, an ethnographer and leading specialist on the Evenki, from the Institute of Ethnology and Anthropology (IEA) in Moscow, was asked to participate in the study of potential social and cultural impacts of the proposed pipeline. She invited me to accompany her. We had enjoyed earlier collaboration (Fondahl \& Sirina 2003), and I had carried out work in the area to the north of Lake Baikal in the early 1990s (Fondahl 1996, 1998). Anna, while having extensive fieldwork experience in many areas of the Russian North with Evenki communities (Sirina 2006, 2012), had never worked in this area.

5 As Anna and I carried out our research in Holodnaia village, interviewing local residents about their aspirations and apprehensions regarding the proposed pipeline, several Evenki individuals declared that we should pay a visit to the Memorial Tree ${ }^{4}$. Most insistent was Viktor Ganiugin, a mathematics teacher at the local school, and initiator of an after-school Evenki culture program for his students. The program addressed his and other Evenki's concerns about the lack of transfer of ecological knowledge from older generations to younger, and the dearth of opportunities for Evenki youth in Holodnaia to spend time in the taiga and learn the skills and ways of their ancestors (cf. Shubin 2007, p. 157). When I had initially met Ganiugin in the early 1990s, he had described his (then new) culture program, and I had visited his brothers' recently established reindeer herd, where a number of Ganiugin's pupils were gathered as part of their curriculum (Fondahl 1998, pp. 124-126).

\section{Traditional tenure}

The Ecological Trail runs from the village of Holodnaia to the Niurundukan (or Niarndarkan) Pass ${ }^{5}$, following the path used by Evenki reindeer herders descending from pastures beyond the pass (fieldnotes 1994, 2005, Simonova 2013, p. 61). Until the mid- $20^{\text {th }}$ century, many Evenki in this area depended on reindeer husbandry, along 
with subsistence and fur hunting, trapping and fishing. They nomadized with their reindeer in the area north of Lake Baikal, visiting the villages along the lake for trading purposes, and, during the Tsarist period and early $20^{\text {th }}$ century, to pay the compulsory fur tribute (Ru. iasak). Evenki reindeer herders of this area called themselves Orochen reindeer people (Evk. oron meaning reindeer), distinguishing themselves from Lamuchen - semi-sedentary Evenki depending on fishing, living along the shores of Lake Baikal (Evk. lamu meaning sea, a term used for Baikal) (see Wure'ertu in the present volume). But most typically, primary identity was with one's clan.

7 Each Evenki clan had its own territory for pasturing deer and hunting according to customary norms, recognized by others, and passed down from generation to generation (Sirina 2006, pp. 73-76, 2012, pp. 136-183, Shubin 2007, pp. 234, 333). Evenki customary law dictated the right of clans to use these territories and to limit the rights of members of other clans to use them without permission. Alienation of land from a clan was uncommon, and usually happened when a group was decimated by disease or in warfare. That is, clans recognized the rights of other clans to distinct territories more or less "in perpetuity", unless exceptional circumstances eradicated a clan and thus freed up its territory. North of Lake Baikal, along the Tyia, Holodnaia, Chaia and Chuia Rivers and the lower reaches of the Verhne-Angara, were the territories of the Kindigir clan. Under the Tsars, their administrative centre was the village of Dushkashan. Farther east, along the valley upper reaches of the Verhne-Angara River the Chilchagir clan predominated, with their administrative centre at Irkana (Shubin 1973, p. 78, 2007, p. 224).

\section{Changing land use and landscapes}

8 Russians began enter the area to the north of Lake Baikal in the mid-1600s, establishing a fortress and trading point (Ru.ostrog) at Verhne-Angarsk in 1647. However, colonization was slow, and the inflow of non-indigenous population was relatively minor for the next couple of centuries. Most in-migrants settled in small agricultural and fishing settlements along or near the north shore of Lake Baikal and in the lower reaches of the Verhne-Angara River. Interactions with Evenki reindeer herders and hunters remained fairly limited (Shubin 1973, p. 78).

After the Revolution and subsequent Civil War, the Soviets began to assert authority over Siberia, including this area. One early move of the Soviets was to establish nomadic "soviets" (councils), to introduce the promises and practices of socialist governance to Siberia's indigenous population. In many areas of Siberia such nomadic soviets were initially established on clan basis. To the immediate north of Lake Baikal the Kindigir Nomadic Council was formed, named after the local clan (Shubin 2007, p. 294).

The State also began to organize the native population for economic purposes, first into Simple Production Unions or guilds, and then into collective farms (Ru. kolhozy). Progress was slow in this part of the Soviet Union. While the more sedentary Evenki who depended largely on fishing were relatively quickly incorporated into guilds and farms, the nomadic herders proved harder to collectivize. In 1932, most Kindigir reindeer herders of this region were incorporated into the " $2^{\text {nd }}$ Five Year Plan" kolkhoz, with its administrative centre first at Dushkashan, and then at Holodnaia. Members of the Chilchagir clan were initially organized into a number of small guilds 
and collectives, though these existed almost only in name. Being farther away from Soviet centres, many Chilchagir avoided collectivization for substantially longer. They eventually were brought into the "Kalinin" kolkhoz, with its centre in Uoian (Shubin 1973, p. 80, 2007, p. 190).

Some Evenki refused to join a collective farm, and to turn their reindeer over - and some were refused entry. Shamans, considered exploiters and charlatans, were banned from membership, and often repressed. Rich reindeer herders, considered by the Soviets as "exploiters of the masses", were also banned from membership; the state confiscated their deer when possible (Tugolukov \& Shubin, 1969, p. 50).

Along with the collectivization, the State encouraged sedentarization - at least of the part of the population that was deemed not to be "productively engaged" in activities that required nomadism. State bureaucrats determined that one or two women "tentworkers" (Ru. chumrabotnitsy) were sufficient to support a brigade of five-six male reindeer herders (via cooking, mending of clothes, etc.); the rest were deemed "unproductive labor", better employed as dairymaids for the collective farms' small dairy herds, in tending the fox farms that were introduced to many Siberian collective farms, and in other, mostly menial jobs in the central villages. Thus, the wives of reindeer herders who were not assigned tent-work jobs were encouraged to settle in the villages. Compulsory education was introduced, often via residential schools, for nomadic children. The village of Holodnaia, like so many other small villages throughout Siberia, was specifically created as a central place to sedentarize, civilize and Sovietize the areas' native nomads, providing permanent housing, a school, basic medical care, and a variety of jobs for those who settled.

of course, through the processes of (partial) sedentarization and formal education, many women and essentially all children and youth spent less time on their clan lands. Family life was disrupted, with most men spending long periods away from their children and, in many cases, their wives, as they continued to nomadize with the herds and hunt for furs. The reduction in the traditional land-based experiential learning among Evenki children, who now spent up to ten months in the village at boarding schools, eroded the transmission of ecological knowledge of their clan territories.

Under the new kolkhoz system, new methods of land allocation were set up. "Scientific rotation" of reindeer pasture was introduced, with scheduled migrations of herd. Hunting territories were assigned with an eye toward "carrying capacity". In practice, many Evenki continued to hunt and herd on their age-old traditional territories (Fondahl 1998, p. 62). However some of these clan territories were abandoned, when individuals (especially rich herders and shamans) fled the area to avoid confiscation of their deer, and then reassigned to other hunters. In other cases, when men failed to meet state-set hunting quotas for furs, their territories could be reassigned to other hunters, including ones from other clans, by farm management.

In the 1950s, a period of village "consolidation" (Ru. ukrupnenie) occurred throughout Siberia. The more remote villages that had served as the centres of small production guilds and kolkhoz were declared "futureless", services were withdrawn from them, and their populations relocated to the larger centres. In northern Transbaikal region, the merging of the "2 $2^{\text {nd }}$ Five Year Plan" kolkhoz and a fishing guild from nearby Dushkashan created the "Friendship" kolkhoz, with Holodnaia as its centre. Nomadic Chilchagir reindeer herders and settled Russians were brought together in the "Kalinin" kolkhoz, centered in Uoian. Tompa, an Evenki (mainly Shemagir clan) village 
along the northeast coast of Lake Baikal was closed, and its population relocated, mostly to the Holodnaia, but also to other settlements. Relocated Shemagir in some cases were assigned new hunting territories nearer to the centres into which they had been relocated, on what had been Kindigir or Chilchagir clan territories. Through these on-going actions of sedentarization, relocation, and the re-assignment of hunting and herding territories, Evenki (Kindigir, Chilchagir and Shemagir) places were sequentially re-made. Yet memories of clan territories remained strong.

The area north of Lake Baikal experienced a short period of reconnaissance activity for minerals and a possible railroad route in the late 1930s. It was in that decade that the non-indigenous population - mostly Russians and Ukrainians - came to outnumber the Evenki in the region. However, they were mostly concentrated in Nizhneangarsk and a few other settlements (Shubin 2007, p. 154). The area remained a relative backwater of the Soviet Union in the decades following World War II. Geology parties came and went, hiring the local reindeer herders as guides and their deer as pack animals to supply their temporary camps. A few small geologists' settlements cropped up near potential mining sites (Pereval, Chaia), and close to some of the key pasturing areas of the Kindigir clan. Some former reindeer herders claimed that the influx of geologists in the 1960s, if small in number, initiated the annihilation of reindeer herding in the area, as both the geologists and their dogs killed the reindeer, and their housing was established on key reindeer pasture (fieldnotes, August 1994).

It was the building of the Baikal-Amur Railway (BAM) in the 1970s that brought massive changes to the area. Thousands of workers poured into the area, to construct the socalled "project of the century". A thin linear feature, the BAM had territorial implications much broader than might be expected. Forest fires accompanied its construction, decimating large swaths of reindeer pasture and hunting grounds. Construction also resulted in the pollution of the local waterways, which caused fish stocks to crash. Reindeer herds were decimated both for meat to feed the newcomers, as the State demanded local farms to support the construction efforts, and due to poaching by the newcomers. By the early 1980s, this age-old occupation had all but disappeared from the area - in 1978 the last 50 deer were removed from the pastures just north of Holodnaia to distant pastures in the northern extreme of the region (fieldnotes, August 1994, Pomishin \& Atutov 1983, p. 19). Alcohol became much more readily available in the once-isolated villages. Many Evenki of the region identify this period of intensified development of their homelands as the climax of their cultural demise (fieldnotes 1994, 2005).

Most recently, in the late 1990s, the proposed construction of an oil pipeline through the area caused consternation among many Evenki, as a new threat to their homelands and one that portended a replay of the ordeals experience in the 1970s. It was these concerns that brought Anna and myself to Holodnaia, and that led to our visit to the Tree of Memory. But before introducing the Tree and Trail, a quick review of the development of legal rights for indigenous peoples in Russia is needed, to provide context for the place-making I describe below.

\section{Legal reforms: Russian law on indigenous rights}

The early post-Soviet years saw dramatic evolution of indigenous rights, at least on paper (Fondahl \& Poelzer 2003, Kriazhkov 2010, 2013). Shortly after the Russian 
Federation declared independence from the Soviet Union, a Presidential Edict called for laws to be adopted that would enable indigenous groups to organize into obshchina roughly translatable as communes or communities - and to receive allocations of land on which to pursue traditional activities, protected from industrial encroachment (President of the Russian Federation 1992, \$22). While it took the better part of a decade for federal law on such rights to be passed, numerous subjects (republics, oblasts, etc.) passed their own laws (Fondahl et al. 2001, p. 547). The Buryat Republic, in which Holodnaia is located, was one of the earliest subjects to pass such legislation, enabling Evenki within its boundaries to create "Evenki peasant (farmers') establishments" (Ru. Evenkiiskie krest'ianskie (fermerskie) hoziaistv) - with the purpose of pursuing "traditional activities" such as reindeer herding and hunting (1991). Evenki in northern Buryatia regularly referred to these "establishments" as clan community (Ru.obshchina) in the early 1990s, and even more so in 2005 (fieldnotes). The "establishments", like clan community, could petition for and receive an allotment of land, on which to pursue such activities. In keeping with local parlance, I will refer to those "Evenki peasant (farmers) establishments" that were formed in Northern Buryatia as clan communities throughout the rest of this article.

A troika of federal laws, with the same purpose eventually followed, at the turn of the millennium (Russian Federation 1999, 2000, 2001). The 1999 federal law outlined the general guarantee of rights of indigenous peoples, and the responsibility and authority of the state and its subjects to protect indigenous peoples. It noted the right of indigenous peoples to "possess" (Ru. vladet') territory for the pursuit of traditional activities, without charge, and to receive support for such activities, on their traditional territories of habitation and economic activity (Russian Federation 2000, \$8.1, 4, italics are mine). The 2000 federal law offered a definition of who is indigenous:

the peoples living in the regions of the North, Siberia and the Far East on the territory of traditional occupancy of their ancestors, maintaining traditional ways of life, economy and trades; numbering less than 50 thousand persons, and considering themselves distinct ethnic communities. (Russian Federation, 2000, §1, italics mine)

It recognized the right of such indigenous peoples to establish clan community, and along with the 1999 law, gave indigenous peoples the right to receive territories for traditional activities ${ }^{6}$.

Several Evenki families in the area north of Lake Baikal decided to form clan community, and tried to register these and receive land allotments for them, prior to the passage of the federal laws (Fondahl 1998, p. 113). In Holodnaia, one family that chose to exercise these new rights was the Ganiugins. Brothers Alexei and Alexander Ganiugin, along with Vladimir Platonov, his son Semën Platonov, and another Evenki, Semën Aeul'ev, created the clan community "Oron" (Evk. oron, reindeer), and applied for lands on which to pursue the "traditional activity" of reindeer herding. The lands they requested were those on which their Kindigir ancestors had hunted and herded (fieldnotes 1994). They received a land allotment north of the village, purchased a small number of reindeer from the neighbouring Chita region ( $\mathrm{Ru}$. oblast'), where reindeer herding had not been fully destroyed, established a base camp at the abandoned geologists' hamlet of Chaia, and began operations, hoping to revitalize this muchdecimated traditional activity (fieldnotes from visit to "Oron" basecamp, 3-4 August 1994). 


\section{The Ecological Trail: re-making a traditional landscape feature}

Viktor Ganiugin, the brother of Alexei and Alexander and mathematics teacher, had meanwhile established an after-school and summer program in the early 1990s, to instruct his pupils in traditional Evenki skills and trades. Creating a small enterprise for educational purposes ( $\mathrm{Ru}$. maloe predpriiatie, also referred to as a shkol'noe hoziaistvo), named "Kindigir", he received a modest land allotment on which to pursue hunting, trapping, fishing and berry gathering. Under the aegis of "Kindigir", students learned to fish and harvest berries, and donated the harvests to the kindergarten and boarding school kitchens. Female students also learned to sew furs from trapped animals into items such as hats, traditional reindeer blankets (Evk. kumalany) and souvenirs (fieldnotes, July 1994). A fellow Evenki teacher at the school noted with respect that "he is practically the only person who preserves the whole [Evenki] complex - fishing, hunting, etc." (interview, 26 July 1994).

Once his brothers received a land allotment for their clan community, in order to pursue reindeer husbandry, and had re-established a small herd through a purchase of deer from a neighbouring region, Viktor initiated a project to bring groups of his students to the base camp of the clan community for a week or so, several times a year. The school children improved the traditional Trail to the reindeer camp base. Historically, in both Tsarist and Soviet times, the Trail had been employed by reindeer herders descending from the mountain pastures to Lake Baikal, for trade and supply purposes. In the 1960s it had also served as their route to provision the geologists working in camps north of Holodnaia. With the demise of reindeer herding by the mid-1980s, use of the Trail decreased.

Along the Ecological Trail, Ganiugin's students built a series of "camps" (Ru. stany) each marked by a simple structure or structures. These include: the bark tipis (Evk. golomo), which the Evenki of this area formerly used as summer residences (Fig. 2); traditional fire pits with conical frames (Evk.guluvun) (Fig. 3); and squat rectangular hunting cabins, adopted from the Russians some three-and-a-half centuries ago (Fig. 4). 
Figure 2. Bark tipi (golomo)

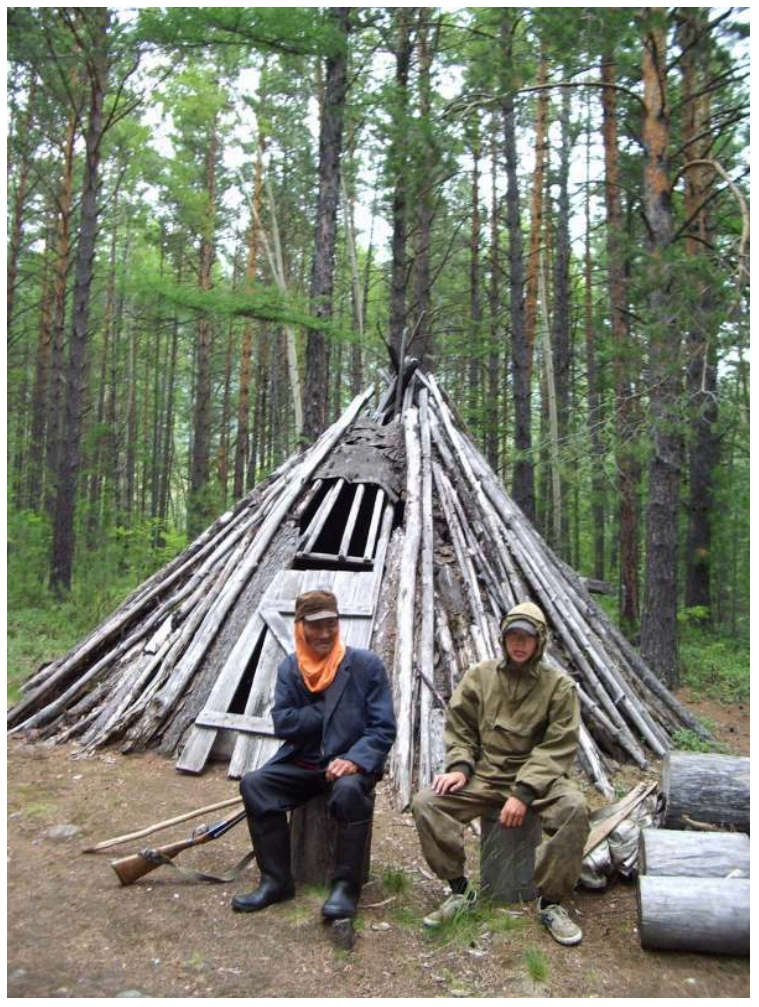

(c) G. Fondahl, August 2005

Figure 3. Conical Frame (guluvun)

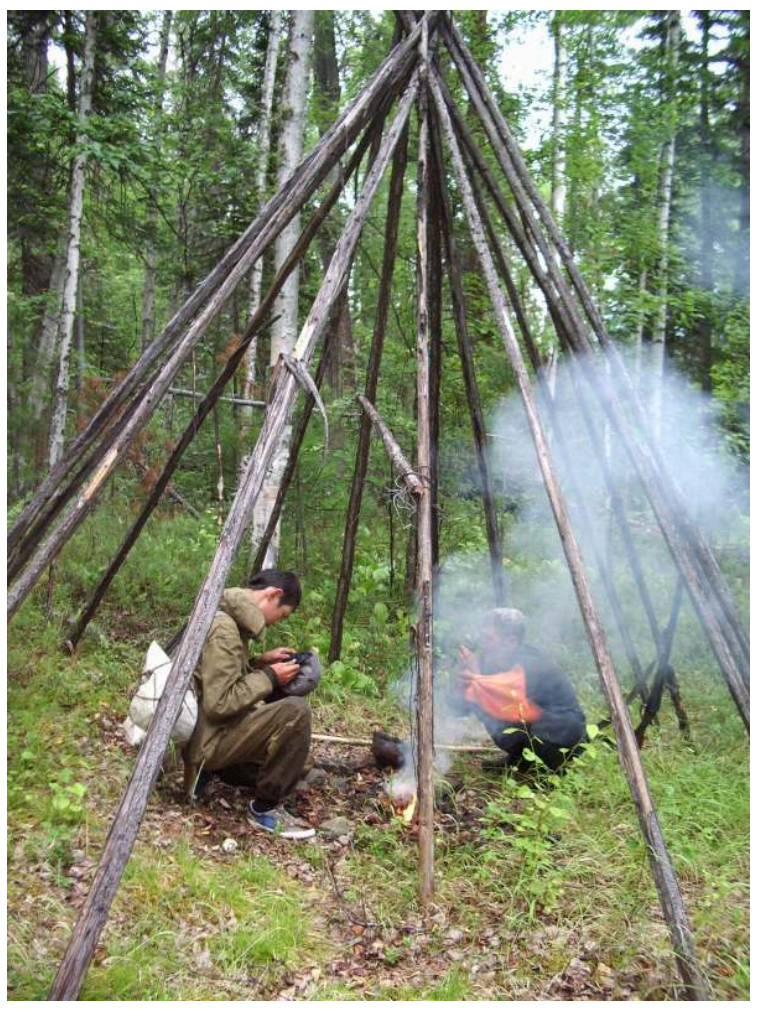

(c) G. Fondahl, August 2005 
Figure 4. Russian Style Hunting Cabin

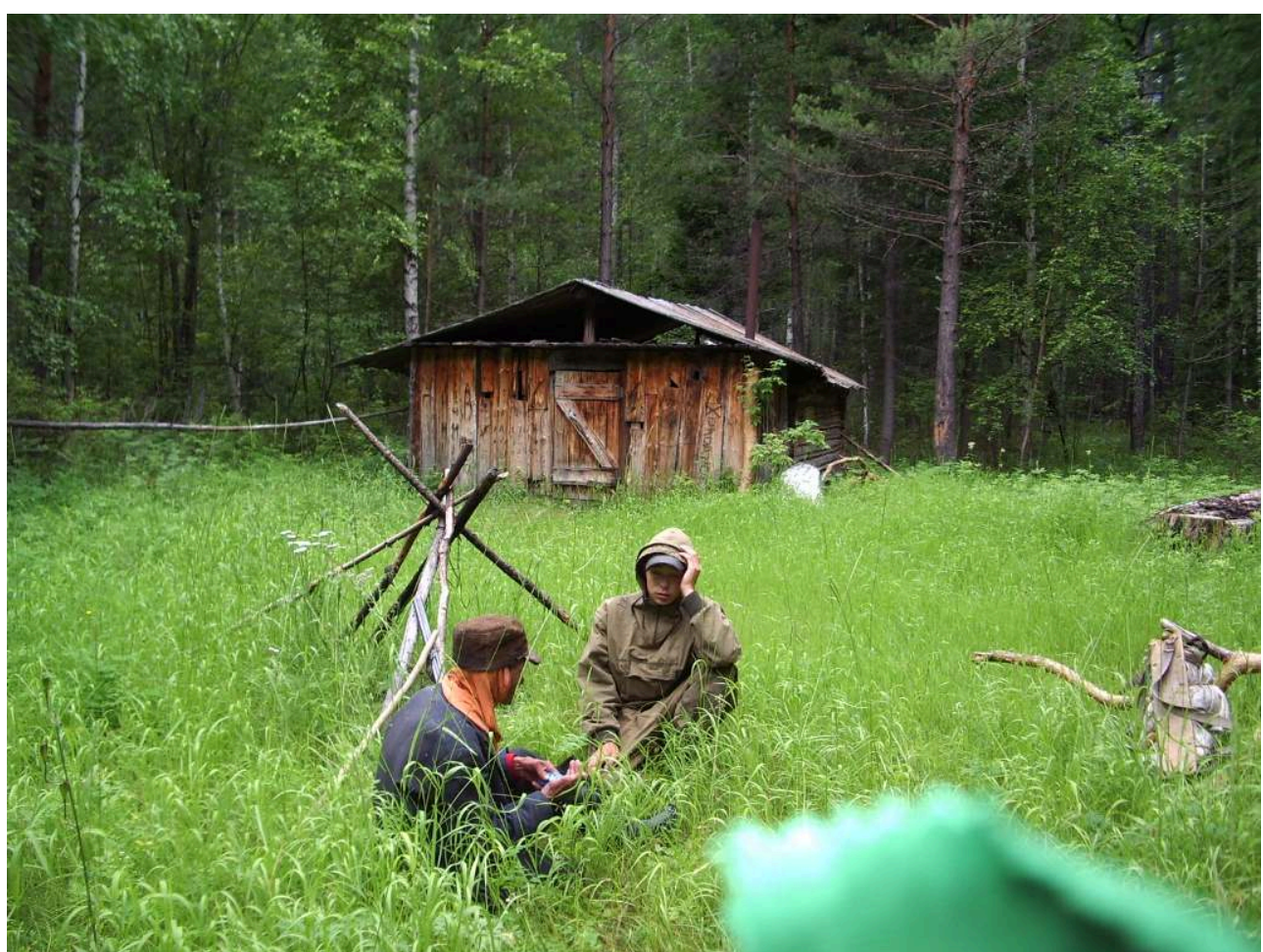

(c) G. Fondahl, August 2005

"The very built form of a place can have the effect of solidifying particular notions about how the world is structured and works", claims geographer Don Mitchell (Mitchell 2000, p. 100). In the "Ecological Trail" project, and in his after-school program more broadly, Ganiugin appropriated the legal discourse that conflates indigeneity with traditionality - choosing to selectively re-materialize the local landscape, in order to solidify conceptions of the territory of the Trail as unambiguously Evenki. "Traditional" Evenki-style structures - (Evk. golomo, guluvun) - punctuate the Trail's route. The Ecological Trail and its structure thus work to solidify notions conflating Evenki with the taiga landscape, for both locals and visitors. What does it mean to be Evenki, or more broadly "indigenous", in early $21^{\text {st }}$ century Russia? Who has the power to define what it means to be indigenous? As noted above, recent legislation on indigenous rights that enables indigenous land claims reified the concept of "traditionality". Indigenous peoples by legal definition are those who pursue traditional activities on the territories of their ancestors. Indigenous peoples can petition for priority usufruct rights to a territory only if it is to be used primarily for "traditional" activities.

After three generations of assimilatory pressures, involving sedentarization, compulsory formal education, in some instances forced relocation, and the annihilation of reindeer herding in some locales, the truly "authentic" natives (those "deserving of indigenous rights") are still imagined as of - and in - the taiga and tundra, a perception potent enough in Russia to find codification in law. It is thus critical that youth now learn about life in the taiga, including the routes historically used by their forbearers, construction techniques of these "traditional" Evenki, and the "traditional" activities of hunting, herding, gathering, and sewing furs, through experiential learning 
characteristic of "traditional" Evenki pedagogy - in a legal environment where their legal rights are entangled with "traditionality".

The very name "Ecological Trail" itself connects to a purported identity trait of indigenous peoples, as underscored in the legislation. "Ecological" invokes imagined connections of innately environmental Evenki with nature, in a continued Rousseauian tradition no less notable in Russia than in North America. This connection is further enhanced by the use of "trail" (Ru. tropa) rather than other possible nouns: "route" (Ru. mashrut') or "road" (Ru. doroga). The moniker "Ecological Trail" was used in applications to the local administration to garner support for the project in the early 1990s, underscoring the role this Trail would play in the experiential curriculum designed to re-connect Evenki youth with nature. It was also the referent most commonly used during Anna's and my visit in 2005. Interestingly, this was no longer the case by the time Veronika Simonova first visited Holodnaia in 2007: colloquially the trail was by then more often referred to as the "Trail of Memory" or "Memorial Trail" (Ru. tropa pamiati) (Simonova, pers. comm., March 2013, Simonova 2013, p. 61, see also Sirina 2012, p. 466). In 2005, during Anna's and my visit, the threat of a new, potentially environmentally threating "mega-project" was very much on the minds of the population of Holodnaia. One reconnaissance transect for the pipeline cut through the taiga across the Trail just above the village, near the beginning of the Trail (Fig. 5). The actuality of the risks associated with the proposed pipeline concerns may have encouraged the re-assertion of the term "ecological", especially in discussions with visiting academics who were engaged in ascertaining local attitudes about the pipeline.

Figure 5. Transect for pipeline

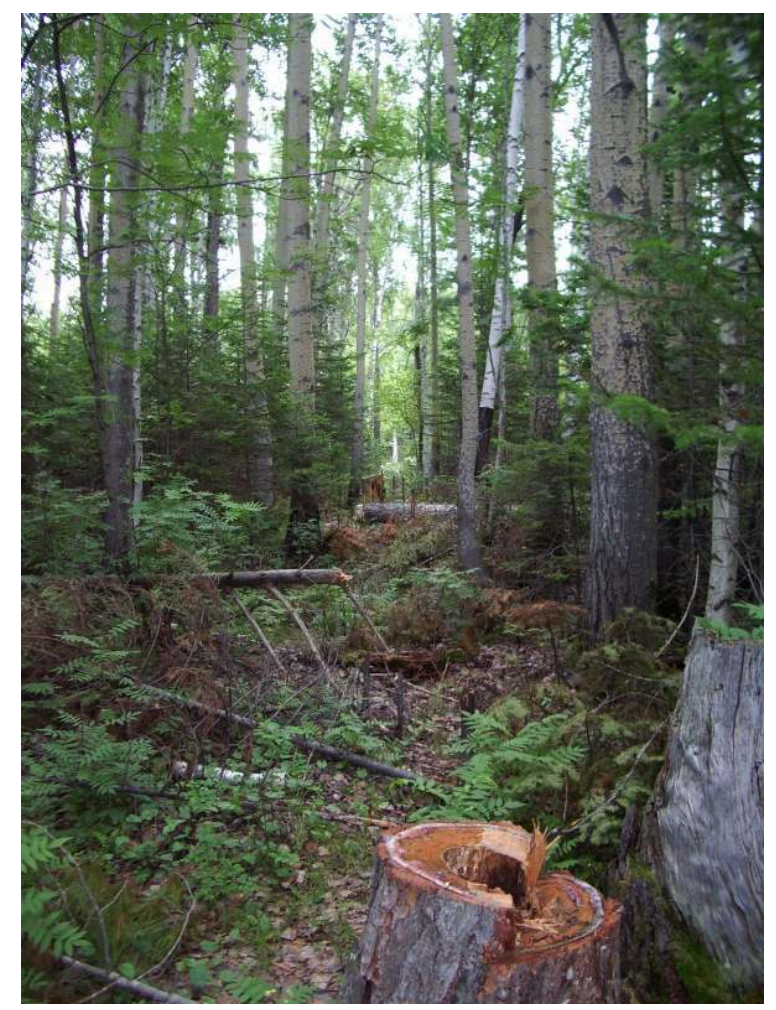

(c) G. Fondahl, August 2005 
There are obviously spatial limits of such indigenous re-territorializations. "Places", Jeffrey Davis notes, "are the result of spatially wider-ranging regimes of power and the ability of some to legitimize one imagining of place over others" (Davis 2005, p. 609). The land north of Lake Baikal was in the later Soviet decades re-visualized by the State as a resource hearth for minerals and timber, and as an important transport corridor linking its centre with its extreme periphery. More recently the area was briefly imagined as an oil pipeline corridor, by Russian and international investors. Environmentalists have envisioned the area as a potential zone of preservation - an imagination fuelled by Lake Baikal's recent designation as a World Heritage site. These are just a few of the externally imposed place-makings that confront the local Evenki.

It has only been beyond the lake's shore and the village edges, in the forests mostly marginal to the larger projects of capital and conservation, and only at limited scales, that the Evenki can resist annihilation of their places, and assert their own visions of landscapes. And it is here that Evenki are performing these small but tenacious placeremakings.

\title{
Memorial Tree: scalar identities asserted
}

Fourteen kilometres up the Trail, we arrived at the "Memorial Tree". The Tree, now a dead snag, is located along the side of the Trail. In 1942, a reindeer herder, Trofim Uronchin, on his way from the reindeer pastures north of Holodnaia to the WWII front, stopped and carved his initials on this Tree's trunk. Under Viktor Ganiugin's leadership, this Tree was elevated to a shrine (see also Simonova 2013, pp. 56-57). The students created a plaque to memorialize the contribution of this person, and all the Evenki of the local Kindigir clan who served in World War II (Fig. 1). The plaque reads (Fig. 6):

Figure 6. Translation of Text on Plaque on Memorial Tree

$$
\begin{gathered}
\text { Memorial Tree } \\
\text { for the Evenki of the Kindigir Clan }
\end{gathered}
$$

called to the ranks of the Soviet Army in the years of the

Great Patriotic War, 1940-44

\begin{abstract}
We ask those passing to remember the traces preserved here
of those who went to defend the Fatherland and in particular

Trofim Afanasevich Uronchin, who went to the front in

1942 and died in 1943 in breaking the Leningrad Blockade.
\end{abstract}

The students of the Kindigir Middle School 
If the "Ecological Trail" is a deliberately constructed or "materialized" "Evenki landscape", rooted in the memories of a pre-Soviet past, its construction in part prompted by an agenda of explicitly reasserting effaced geographies of "traditionality", the Memorial Tree serves as a more complex or stratified commemoration. It celebrates Evenki as citizens, taking their place alongside other peoples of the Soviet Union, to make sacrifices for the protection of the greater homeland (Accomplished hunters, indigenous peoples played an important role as snipers in WWII, and suffered high casualties.). Yet the Tree also marks prominently the local lineage of Uronchin - he was Evenki but also Kindigir.

The clan name Kindigir has also recently been re-inscribed on the territory as the name of the middle school in Holodnaia. As well, the local township, of which Holodnaia serves as the centre, is the "Kindigir Evenki Rural Administration" (Supreme Soviet of the Buryat Soviet Socialist Republic 1992) ${ }^{7}$. Kindigir are once again asserting more localized territorial identity and associated rights to the territory, in an environment where law allows land to be assigned on the basis of connection to "ancestral territory". Concerns over clan community allocations to non-Kindigir, as well as more general concerns and competition over land use priorities, have stimulated such assertions of both Evenki and more specific Kindigir territorial identities.

\section{Performing the walk: the researchers' role}

I now want to turn to consider the purpose of our walk, arranged by Viktor Ganiugin, along the Ecological Trail to the Memorial Tree. I argue that it involved three main and intertwined objectives. Firstly, it provided for a temporary assertion of Evenki authority over ourselves, reversing the typical role of researcher/researched, and specifically involving the instruction of us via Evenki pedagogical methods of experiential learning. Secondly, the walk enabled our witnessing the assertion of Evenki, and more specifically Kindigir, rights to this territory. Thirdly, the walk conveyed a message about indigenous revival to us - but also potentially through us to others involved in or sympathetic to such struggles.

Viktor Ganiugin suggested as our guide Arkadii Lekarev, a 73-year old Evenki intimately familiar with the territory, and with Evenki culture and protocols (Fig. 7). Lekarev, also of the local Kindigir clan, was from a reindeer herding family. His life straddled and perhaps epitomized the various phases of the Soviet period experienced by the Evenki of this region. Born in the bush in 1932, he had grown up as a herder on the land. Sent to study at the Evenki boarding school in Ulan-Ude, he returned after $6^{\text {th }}$ grade to his birth-region and took up reindeer herding (V. Ganiugin, personal communication, July 2005, Shubin 2007, p. 171). He had worked for geologist parties, providing transport services and guiding the parties through the taiga, which he knew exceptionally well. When reindeer herding was finally fully annihilated in the 1980 s he became a hunter. Lekarev had witnessed the changes brought by geological reconnaissance in the late 1950s/1960s, by the railroad in the 1970s/1980s, and by the "transition to capitalism" in the 1990s. In 2005 he lived in grim poverty, subsisting on fishing, hunting and the occasional sale of baskets (Evk. potki), for which he holds a reputation as a master craftsman. Lekarev was one of the few remaining Evenki in Northern Transbaikal region who was fluent in his language - he was "a real Evenki" according to the discourse of some villagers. 


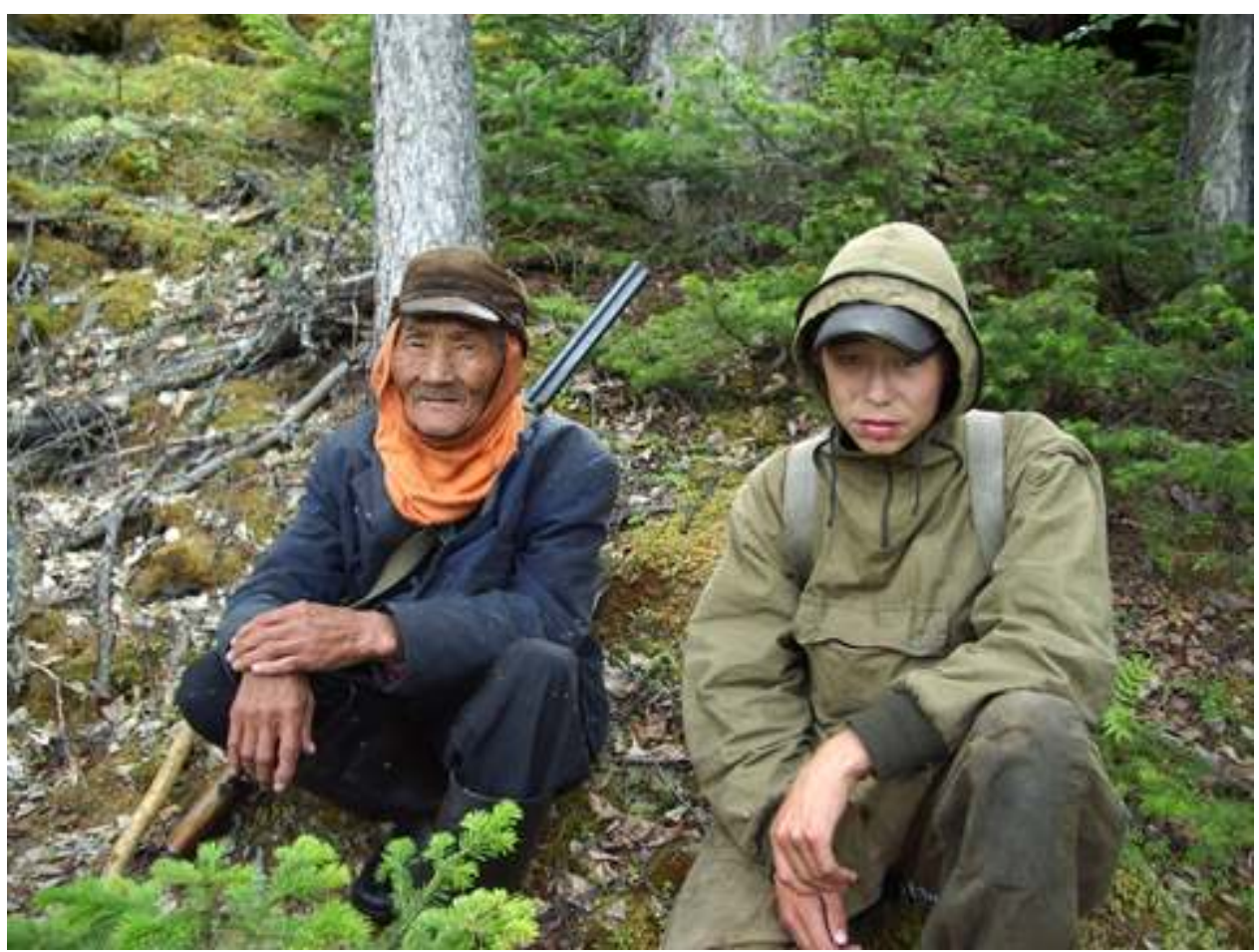

(c) G. Fondahl, August 2005

Given the presence of bears in the area, it was considered necessary for someone in the group to carry a rifle on this trip. Yet rules on firearms circumscribe their ownership and transport. Evenki, along with other citizens, have to register them, and have to have the right papers to carry them. Our visit corresponded with the season of encephalitic tick activity, requiring attention to protective clothing against these insects. It took a couple of days to acquire a gun, to fill in the appropriate paperwork and to arrange to borrow the necessary clothing. Midmorning on July 12, 2005, Lekarev donned his a traditional backboard (Evk. ponianga) that served as a pack. His greatnephew Denis Shangin also joined us. We headed out of the village along the Ecological Trail into the taiga.

Shortly thereafter, perhaps another 15 minutes, we traversed a pipeline reconnaissance transect cut through the woods. We then started to climb through the forest of larch, pine and birch. In an hour or so we came upon the first "station" or assemblage of Evenki structures built by the students. We paused at this station for a few moments, as Lekarev took a smoke break. The mosquitoes encouraged movement rather than rest, so Anna and I inspected the interiors of the structures.

Our research on the pipeline, though considered of import, was village-based. During our work in the village we were thus not experiencing a "true Evenki landscape", nor were we learning about Evenki concerns "in an Evenki way". Thus, it was important to take us out of the spaces of village-based interviewing, to invert the roles of authority, and to instruct us, if only briefly and superficially, in Evenki ways and by Evenki (experiential) means about Evenki concerns regarding the land and culture. It was important that we inhabit this Evenki landscape corporeally, if but briefly. To understand the landscape of Trail and Tree we needed to experience it with an 
authoritative Evenki elder. This educating of us was deemed worth the risks that our guides and we would endure - most notably that of encephalitic ticks, but also of bears, and simply of fatigue from a $28 \mathrm{~km}$ (return) hike (I note once again that Lekarev was $\left.73^{8}\right)$.

While in the village Anna and I exercised relative autonomy, in the taiga our decisionmaking was relinquished to Lekarev, who decided what pace to set, when to take breaks, when to eat - regulating our experience of the Ecological Trail. Powerknowledge relations shifted. Lekarev instructed us in appropriate conduct in this place, mostly through actions not words. Indeed the hike was relatively free of words and of food - reproducing documented Evenki patterns of demeanour in the taiga, where talking and eating take place mostly once in camp (Vasilevich 1969, p. 232, Shubin 2007, p. 45).

The Trail itself was sometimes obvious; at other times to the untrained eye it disappeared, as we followed gravel bars along the Holodnaia River, or traversed meadows of thigh-high grass with no apparent course. We required the skill of Lekarev to navigate - to bring us from gravel bar back to the river's shore at the right location, to issue from the meadow at that spot where Trail re-entered the forest. We theoretically depended on his protective capacity as the gun-bearer for the group. The walk allowed us to experience this "real Evenki's", this Kindigir's close knowledge of and engagement with this place, his clan's "traditional territory".

41 Accompanying us was Lekarev's grand-nephew, Denis Shangin (Fig. 7). The expedition thus was both demonstrative and heuristic: Denis could demonstrate to us what youth know of their traditions and territories (partially learned through Viktor Ganiugin's training programs), while he would also receive instruction through observing his grand-uncle during the day's sojourn - a process we would witness, while we ourselves were also educated.

42 Anthropologists Julie Cruikshank and Tatiana Argounova, in recounting their own experiences of being taken to visit remote Sakha ${ }^{9}$ memorials in the taiga several hundreds of $\mathrm{km}$ northeast of Holodnaia, note that "indigenous peoples in arctic and sub-arctic regions are trying to reconstruct links between memories and knowledge in ways that simultaneously reestablish meaning locally (especially for young people) and convey clear messages to distance audiences" (Cruikshank \& Argounova 2000, p. 97). Ganiugin's Ecological Trail project was directed in large part to re-establishing a landscape of local meaning for his Evenki students. Denis's participation in this hike allowed us to witness this re-connection.

Yet our hike was also about communicating Evenki visualizations of their spaces, and Evenki materializations of these spaces - in a word, Evenki geopolitical agendas - to "distant audiences". Anna and I had both adequately indicated our interest in Evenki culture. Though Anna had not previously worked in this area, her work with Evenki in the neighbouring Irkutsk province is known by the local intelligentsia, including Viktor Ganiugin. Anna combined the stature of working at the most prestigious anthropological institute in the country with being of somewhat local birth (she was from Irkutsk, a city near the southern end of Lake Baikal). Her past work, her workplace, and her origin all suggested her as a potentially useful and sympathetic accomplice.

I had conducted research on land rights and land claims in the region in the early1990s, and had interviewed Viktor Ganiugin in 1994, subsequently sharing the published 
results of that research (Fondahl 1998) with him. My international status provided yet other channels for communication. We were thus credible intermediaries, worth Ganiugin's and Lekarev's investment of time and effort, promising channels for the recording and dissemination of information on this local place-making project. Ganiugin could use our voices as conduits for expressing local Evenki concerns over other potential re-makings of this - this Evenki and Kindigir place - the re-makings schemed by distant powers: by oil and pipeline companies, by Baikal conservationists, by rich Russians desirous of vacation homes on the shore of Lake Baikal. Our visit to Memorial Trail, our walking of the Ecological Trail helped both to concretize the local importance of these features, and to connect these intimate Kindigir/Evenki spaces of re-territorialisation to wider scales and -scapes of indigenous place-(re)making.

Reaching the Memorial Tree in the late afternoon, we built a small fire, and brewed another cup of tea. We made offerings to the place, of candies, coins and vodka, as Evenki protocol demands. We then began our return trip, following Lekarev as he nimbly negotiated his way down the Trail. Stopping one more time for tea, we would reach the village late in the evening, at the latter edges of twilight.

\section{Conclusion}

Geopolitical power, Fraser McDonald notes (McDonald 2006, p. 55), is exercised through the experiences of sights and spectacles. Produced by Ganiugin, directed by Lekarev, our hike along the Ecological Trail to the Memorial involved us simultaneously as audience and actors. We experienced the sites/sights but also enacted this spectacle of indigenous micro-geopolitics.

During the past century, Evenki were forced to spatially dissimulate their cultural landscapes. Exogenous place-makings - kolkhoz villages, a railroad, mines, forest clearcuts, and so forth - have long functioned as imposed forms of representation and regulation, first Soviet, now peri-capitalist. The local Evenki are contesting these external place-makings. They are re-creating landscapes proclaimed to be explicitly Evenki, if at small scales and peripheral locations. They are doing so within a newly evolving political context, following visualizations in part imposed on them by Russian law about what it means to be indigenous. They are appropriating these legal definitions that link rights to "traditional" or "ancestral" territory and to the practice of traditional activities. They are creating material landscapes to further solidify their claims to their territories. Some in Holodnaia are proclaiming "Kindigir" landscapes, further localizing their claims.

And they are asserting geopolitical power by the carefully-staged embedding of outsiders in the spaces of such political projects - to educate and to connect locally constructed landscape of resistance and revival to wider scales of indigenous geopolitical actions ${ }^{10}$. Our walk is but one example of many such projects taking place in the Siberian taiga. 


\section{BIBLIOGRAPHY}

Cruikshank, J. \& T. Argounova 2000 Reinscribing Meaning. Memory and Indigenous Identity in Sakha Republic (Yakutia), Arctic Anthropology 37(1), pp. 96-119.

Davis, J. 2005 Representing Place. "Deserted Isles" and the reproduction of Bikini Atoll, Annals of the Association of American Geographers 95(3), pp. 607-625.

Fondahl, G. 1996 Contested terrain. Changing boundaries and identities in Southeastern Siberia, Post-Soviet Geography 37(1), pp. 3-15.

1998 Gaining Ground? Evenkis, Land and Reform in Southeastern Siberia (Wilton, CT, Allyn and Bacon).

Fondahl, G., O. Lazebnik, G. Poelzer \& V. Robbek 2001 Native "land claims", Russian style, Canadian Geographer 45(4), pp. 545-561.

Fondahl, G. \& G. Poelzer 2003 Aboriginal land rights in Russia at the beginning of the twenty-first century, Polar Record 39(309), pp. 111-122.

Fondahl, G. \& A. A. Sirina 2003 Working borders and shifting identities in Northeastern Siberia, Geoforum 34(4), pp. 541-556.

2006a Rights and risks. Evenki concerns regarding the proposed Eastern Siberia-Pacific Ocean pipeline, Sibirica 5(2), pp. 115-138.

$2006 \mathrm{~b}$ Oil pipeline development and indigenous rights in Eastern Siberia, Indigenous Affairs 2-3, pp. 58-67.

Kriazhkov, V. A. 2010 Korennye malochislennye narody Severa $v$ rossiiskom prave [Indigenous numerically small peoples of the North in Russian law] (Moscow, Norma).

2013 Development of Russian legislation on Northern indigenous peoples, Arctic Review on Law and Politics 4(2), pp. 140-155.

Lefebvre, H. [1984] 1991 The Production of Space, translated by Nicholson-Smith (Oxford, Blackwell).

McDonald, F. 2006 Geopolitics and the 'Vision Thing'. Regarding Britain and America's first nuclear missile, Transactions of the Institute of British Geographers 31(1), pp. 53-71.

Mitchell, D. 2000 Cultural Geography. A Critical Introduction (Oxford, Blackwell).

Pomishin, S. B. \& A. A. Atutov 1983 Olenevodstvo v Buriatii. Problemy puti razvitiia [Reindeer husbandry in Buryatia. Problems and paths of development] (Ulan-Ude, Buriatskoe knizhnoe izdatel'stvo).

President of the Russian Federation 1992 O neotlozhny merah po zashchite mest prozhivaniia $i$ hoziaistvennoi deiatel'nosti malochislennyh narodov Severa [On urgent measure to defend the places of habitation and economic activities of the numerically small peoples of the North], Edict \#397 of the President of the Russian Federation, 22 April.

Russian Federation 1999 O garantiiah prav korennyh malochislennyh narodov Rossiiskoi Federatsii [On guaranteeing the rights of the indigenous numerically small peoples of the Russian Federation] Russian Federal Law 82-F3, 30 April.

2000 Ob obshchih printsipah organizatsii obshchin korennyh malochislennyh narodov Severa, Sibiri $i$

Dal'nego Vostoka Rossiiskoi Federatsii [On general principles for the organization of clan community of the indigenous numerically small peoples of the North, Siberia, and the Far East of the Russian Federation], Russian Federal Law 104-F3, 2 July.

20010 territoriiah traditsionnogo prirodopol'zovaniia korennyh malochislennyh narodov Severa, Sibiri $i$ 
Dal'nego Vostoka Rossiiskoi Federatsii [On territories of traditional nature use of the indigenous numerically small peoples of the North, Siberia, and the Far East of the Russian Federation], Russian Federal Law 49-F3, 7 May.

Shubin, A. S. 1973 Kratkii ocherk ètnicheskoi istorii èvenkov Zabaikal'ia (XVII-XX vv.) [A brief monograph of the ethnic history of the evenki of transbaikal region $\left(17^{\text {th }}-20^{\text {th }}\right.$ centuries] (Ulan-Ude, Buriatskoe knizhnoe izdatel'stvo).

2007 Èvenki (Ulan-Ude, Respublikanskaia tipografiia).

Simonova, V. 2013 The Evenki Memorial Tree and Trail. Negotiating a Memorial Regime in the North Baikal, Siberia, Journal of Ethnology and Folkloristics 6(1), pp. 49-69.

Sirina, A. A. 2006 Katanga Evenki in the $20^{\text {th }}$ Century and the Ordering of Their Life-world (Edmonton, CCI Press).

2012 Èvenki i èveny v sovremennom mire [Evenki and Evens in the contemporary world] (Moscow, Vostochnaia Literatura).

Sirina, A. A. \& G. Fondahl 2006 Èvenki severnogo Pribaikal'ia i proekt stroitel'stva nefteprovoda "Vostochnaia Sibir'-Tihii okean" [The Evenki of Northern Cisbaikal region and the "Eastern Siberia-Pacific Ocean" pipeline construction project], Issledovaniia po Prikladnoi i Neotlozhnoi Ètnologii 186.

Supreme Soviet of the Buryat Soviet Socialist Republic 1992 Postanovlenie "Ob obrazovanie na territorii Buriatskoi SSR èvenkiiskih sel'skih Sovetov narodnyh deputatov [Decree "On the formation on the territory of the Buryat SSR of Evenki rural councils of people's deputies"], 17 January 1991, Vedomosti Verhovnogo Soveta Respubliki Buriatiia 2, pp. 61-62.

Tugolukov, V. I. \& A. S. Shubin 1969 Kolhoznoe stroitel'stvo u èvenkov Severnoi Buriatii i ego vliianie na ih byt i kul'turu [Collective farm construction among Evenki of Northern Buryatia and its influence on their lifeway and culture], Ètnograficheskii sbornik (Ulan-Ude) 5, pp. 42-64.

Vasilevich, G. M. 1969 Èvenki. Istoriko-ètnograficheskie ocherki (XVIII-nachalo XX v.) [Evenki. Historicalethnographical monograph (18 $8^{\text {th }}$ beginning of $20 t^{h}$ c.)] (Leningrad, Nauka).

Wure'ertu (this volume) Evenki migrations in early times and their relationship with rivers, Études mongoles \& sibériennes, centrasiatiques \& tibétaines 49 [online, URL: http:// journals.openedition.org/emscat/3196, accessed 20 December 2018].

\section{NOTES}

1. Russian Federation law recognizes "indigenous numerically small peoples of the North" as a special category of peoples warranting legal protection due to their small numbers and "traditional" ways of life (Russian Federation 1999, Kriazhkov 2010, 2013, Fondahl \& Poelzer 2003).

2. Henri Lefebvre argues that space is produced by visualization, administration and materialization (Lefebvre [1984] 1991, pp. 33). Indigenous places have often been re-made by colonial and other external forces, which have visualized a different use of the space, and then performed administration and material reconstruction, that altered these spaces and the places they encompass. Indigenous communities challenge these exogenous place-makings, re-making the places by asserting their visualizations through concrete materializations and transitory but recurrent enactments.

3. The pipeline was later re-located to outside of the Lake Baikal watershed. 
4. Simonova also notes the locals encouraging her to visit the Trail and Tree (Simonova 2013, p. 60).

5. Shubin recorded Niarndarkan (or Iandarkan) as the Evenki name for the Holodnaia River as well (Shubin 2007, pp. 155, 179, 314).

6. The laws provided for the transfer of rights of use and inheritance and certain exclusionary rights over its territory, though not for "ownership" akin to fee-simple rights common in the West. The 2001 federal law enabled the creation of Territories of Traditional Nature use, but has remained unimplemented. Revisions to the federal legal code in 2004 reduced significantly the rights of indigenous peoples, no longer allowing land to be transferred to clan community "in perpetuity" or "rent-free", but rather introducing a 25-year lease period (Kriazhkov 2010, p. 83).

7. Indeed, it is worth noting the introduction of the term Evenki once again in the name of the rural councils. In the early Soviet period the names of the units on administrative level up from "rural administrations", the districts (Ru. raiony or, locally, Evk. aimakil) were, in Northern Buryatia prefaced with the word Evenki: the Severobaikal Evenki Aimak (Ru. Severobaikal'skii evenkiiskii aimak) and the neighboring Baunt Evenki Aimak. However the word Evenki fell way from the official titles by the 1930s, as "nationalist tendencies" became increasingly suspect and subject to punishment.

8. Indeed, in 1994, Yuri Chernoev, also of Holodnaia, had organized a somewhat similar expedition, to his clan community's territory - though by tank not foot. Once there, he instructed me to turn on my tape recorder, and proceeded to provide a political commentary on indigenous rights and struggles in general and his rights to the territory in specific. It was important to him that I heard about these rights while on the land (fieldnotes 1994).

9. Another indigenous people of Siberia, though not a "Numerically Small People" - see footnote 1 , above.

10. Our hike along the Ecological Trail to the Tree of Memory was an important element of our local research regarding of the potential social impacts of the pipeline, the results of which were published, among other places, in a journal focused on indigenous geopolitical action and rights around the world (Fondahl \& Sirina 2006b). The pipeline route was subsequently moved out of the Lake Baikal watershed, to the North; its construction is affecting other Evenki communities.

\section{ABSTRACTS}

In this paper I explore how the Evenki of southeast Siberia resist place-annihilation caused by both the direct actions of resource development and the indirect effects of formal education that cause a decline of indigenous place-based knowledge. I argue that they do so by the production and presentation of landscape elements that assert and educate about Evenki place-based identity. Through performing the landscape of an "Ecological Trail" and a "Memorial Tree", for both Evenki youth and visitors from afar, Evenki elders appropriate legal discourses that conflate indigeneity with traditionality, manipulate memories of indigenous pasts (pre-Soviet and Soviet), communicate place-based cultural teachings and celebrate Evenki survival and renewal in the face of continued threats of place-annihilation.

Dans cet article, j'explore la façon dont les Évenks du Sud-Est de la Sibérie résistent à l'anéantissement de leurs terres. Celui-ci est causé tant par les actions directes de l'exploitation des ressources que par les effets indirects de l'éducation formelle ayant pour conséquence le 
déclin des savoirs environnementaux autochtones. Je suggère que les Évenks de cette région résistent par l'intermédiaire de la production et de la présentation d'éléments de paysage qui affirment et transmettent une identité évenke ancrée dans ce lieu. À travers la mise en scène d'un paysage au travers d'un "sentier écologique " et d'un arbre commémoratif, tant pour les jeunes Évenks que pour les visiteurs venus de loin, les aînés évenks s'approprient les discours juridiques qui combinent «indigénéité » et «traditionalité », manipulent la mémoire des passés autochtones (pré-soviétique et soviétique), transmettent les enseignements culturels ancrés dans le paysage et célèbrent la survie et le renouveau des Évenks face aux menaces continuelles de l'anéantissement des terres.

\section{INDEX}

Keywords: indigenous, Evenki, Siberia, Baikal, re-territorialization, identity, place-based identities

Mots-clés: autochtones, Évenk, Sibérie, Baïkal, identité, re-territorialisation, identités territoriales

\section{AUTHOR}

\section{GAIL FONDAHL}

Dr. Gail Fondahl is a Professor of Geography at the University of Northern British Columbia, Canada. Her research has focused on the legal geographies of indigenous rights in the Russian North, the historical geography of reindeer husbandry in the Russian North, and co-management of resources and research in northern British Columbia. She is currently also involved in research on Arctic sustainability, with a focus on its cultural, legal and governance dimensions. Fondahl recently co-edited the second Arctic Human Development Report (AHDR-II, 2015), and Northern Sustainabilities. Understanding and Addressing Change in the Circumpolar World (Springer, 2017), and co-authored Arctic Sustainability Research. Past, Present and Future (Routledge, 2017).

Gail.Fondahl@unbc.ca 